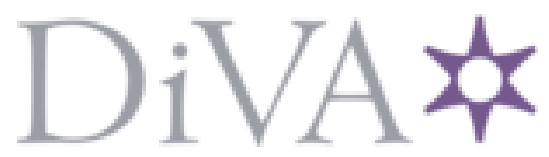

http://www.diva-portal.org

This is the published version of a paper published in RSC Advances.

Citation for the original published paper (version of record):

Bora, T., Myint, M T., Al-Harthi, S., Dutta, J. (2015)

Role of surface defects on visible light enabled plasmonic photocatalysis in $\mathrm{Au}-\mathrm{ZnO}$

nanocatalysts.

RSC Advances

Access to the published version may require subscription.

N.B. When citing this work, cite the original published paper.

Permanent link to this version:

http://urn.kb.se/resolve?urn=urn:nbn:se:kth:diva- 176610 
ART-TOC-ENTRY

Visible light photocatalytic activity of the plasmonic gold-zinc oxide ( $\mathrm{Au}-\mathrm{ZnO}$ ) nanorods (NRs) is investigated with respect to the surface defects of the ZnO NRs, controlled by annealing the NRs in ambient at different temperatures.

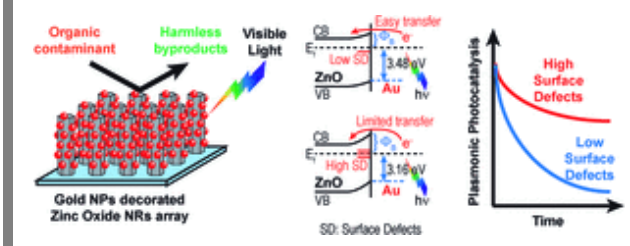

\title{
Role of surface defects on visible light enabled plasmonic photocatalysis in Au-ZnO nanocatalysts ${ }^{\dagger}$
}

${ }^{\dagger}$ Electronic supplementary information (ESI) available. See DOI: 10.1039/c5ra16569e

T. Bora, ${ }^{*}$ a

M. T. Z. Myint, ${ }^{\text {a }}$

S. H. Al-Harthi,

J. Dutta ${ }^{*}, \mathrm{a}, \mathrm{c}$

aChair in Nanotechnology, Water Research Center, Sultan Qaboos University, P. O. Box 17, Al Khoud - 123, Oman. Email: joydeep@kth.SE; tanujjal@squ.edu.om

${ }^{b}$ Department of Physics, College of Science, Sultan Qaboos University, P. O. Box 36, Al Khoud - 123, Oman.

${ }^{\mathrm{C}}$ Functional Materials Division, School of Information and Communication Technology, KTH Royal Institute of Technology, Isafjorsgatan 22, SE-164 40 Kista, Sweden.

\begin{abstract}

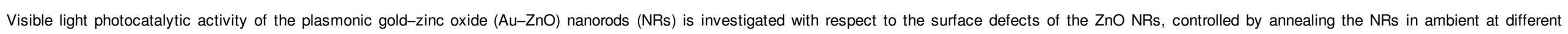

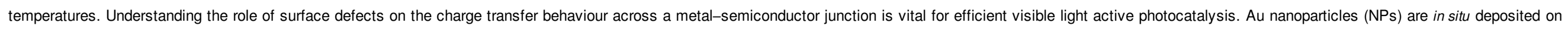

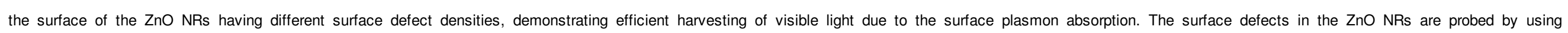

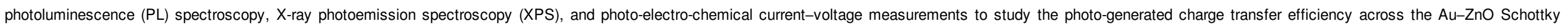

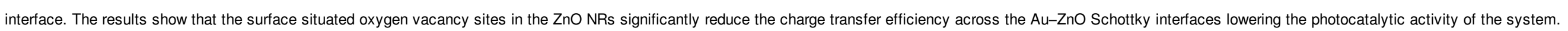

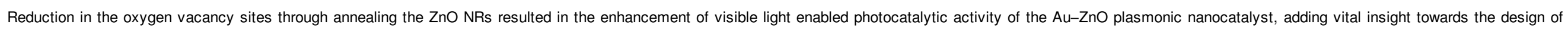
efficient plasmonic photocatalysts.
\end{abstract}

\section{Introduction}

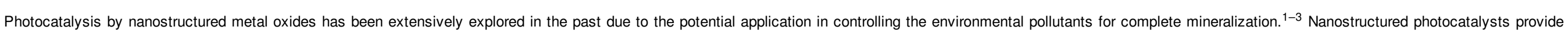




\section{rsc_RA_c5ra16569e}

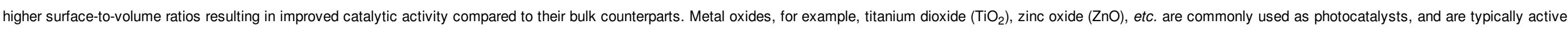

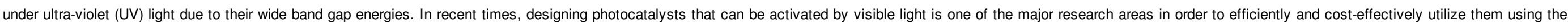

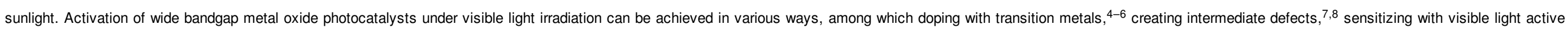
dyes or other semiconductors materials, ${ }^{9-11}$ narrow bandgap semiconductor coupling ${ }^{12-14}$ etc. are some of the commonly used methods.

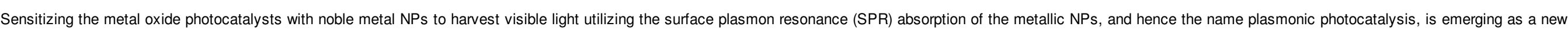

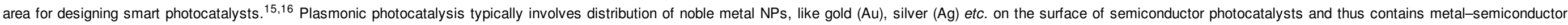

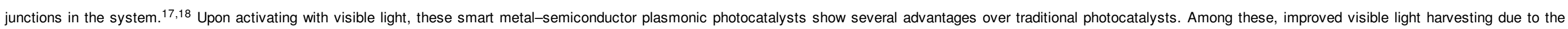
localized SPR absorption and enhanced photo-generated charge separation across the metal-semiconductor interface are primarily important for efficient visible light photocatalytic degradation of pollutants. ${ }^{16,19}$

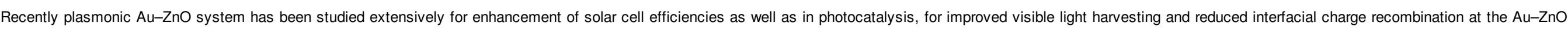

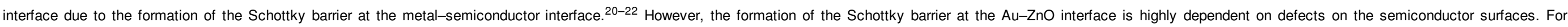

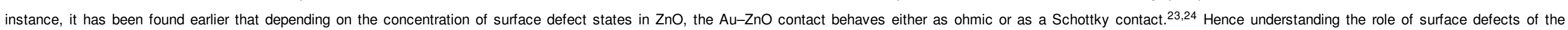
semiconductor material on the formation of Schottky barrier at the metal-semiconductor interface and thereby its contribution to the plasmonic photocatalysis by metal-semiconductor photocatalysts is vital.

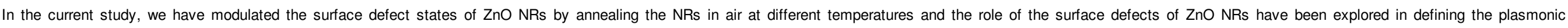

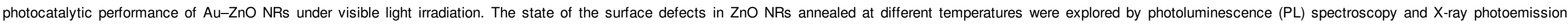

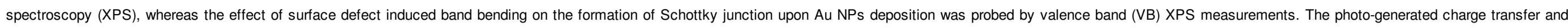
charge separation efficiency across the Au-ZnO Schottky junctions were also explored and discussed from the photo-electro-chemical current-voltage ( $I-V)$ measurements of the Au-ZnO NRs.

\section{Experimental}

\section{Synthesis of ZnO NRs}

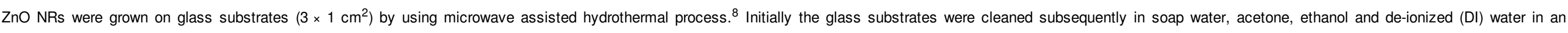

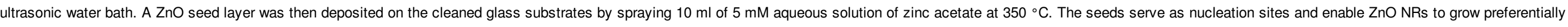

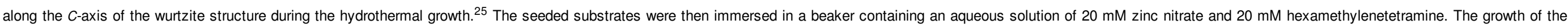

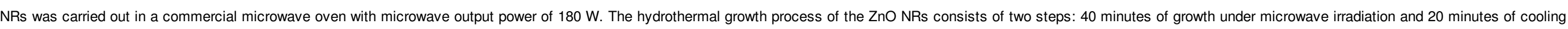

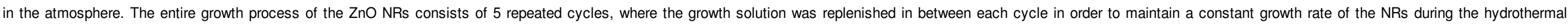
process. Finally the substrates were retracted from the chemical bath, rinsed thoroughly with DI water followed by drying in an oven at $85^{\circ} \mathrm{C}$ for 1 hour and stored until further use.

\section{Deposition of Au NPs on ZnO NRs}

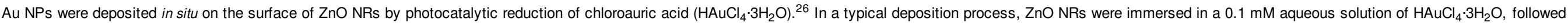

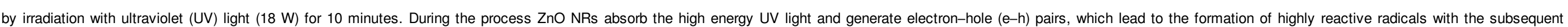
reduction of $\mathrm{AuCl}_{4}{ }^{-}$ions to metallic Au on the surface of the NRs. After UV irradiation, the Au-ZnO NRs coated glass substrates were rinsed with copious amount of $\mathrm{DI}$ water and dried in air at $85{ }^{\circ} \mathrm{C}$.

\section{Photocatalytic tests}

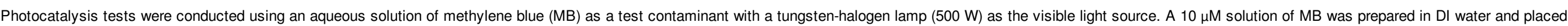

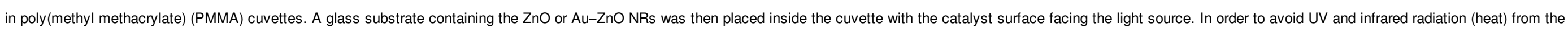

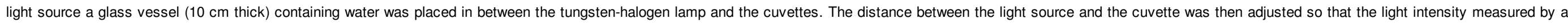




\section{rsc_RA_c5ra16569e}

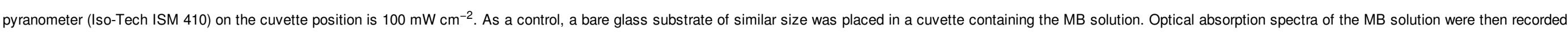

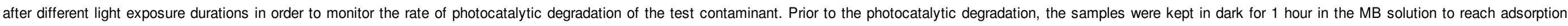

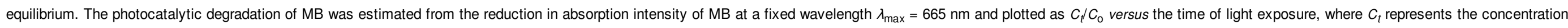
of $\mathrm{MB}$ at time $t$ and $C_{0}$ represents the initial concentration of $\mathrm{MB}$.

\section{Characterization}

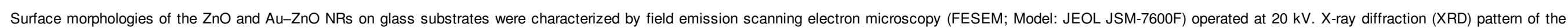

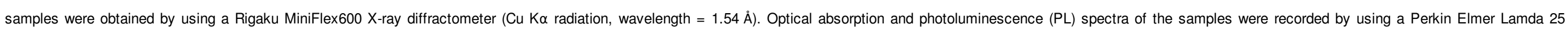

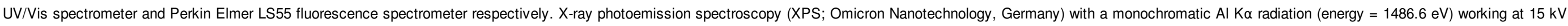

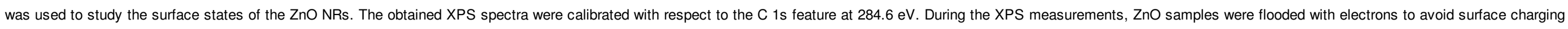
during XPS measurements.

\section{Photocurrent measurement in Au-ZnO NRs}

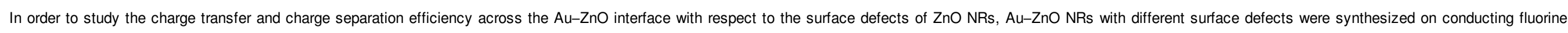

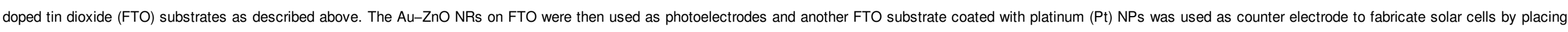

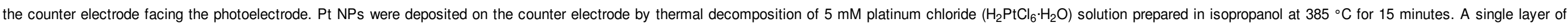

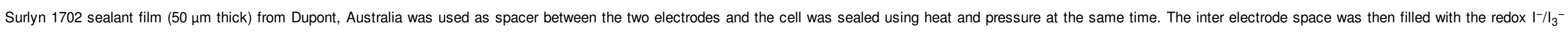

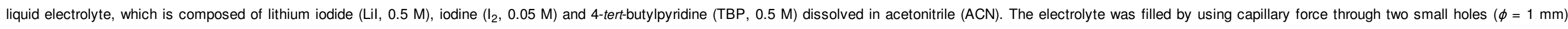

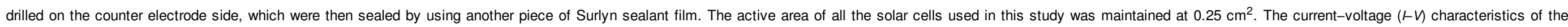

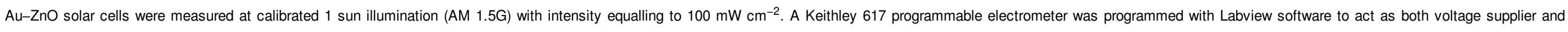
current sensing unit to acquire the $\vdash V$ characteristics. The fill factor (FF) of the Au-ZnO solar cells was calculated from their $\vdash V$ curves by using the following equation:

$$
\mathrm{FF}=\frac{P_{\text {max }}}{P_{\text {th }}}=\frac{I_{\text {max }} \times V_{\text {max }}}{I_{\mathrm{SC}} \times V_{\mathrm{OC}}}
$$

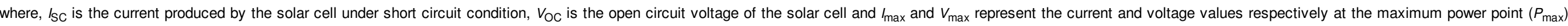
which can be delivered by the solar cell to an external load.

\section{Results and discussions}

\section{Photocatalytic degradation of MB using Au-ZnO NRs}

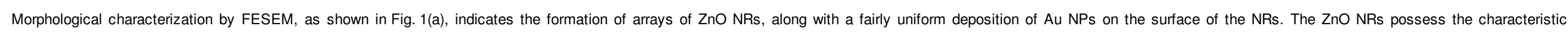

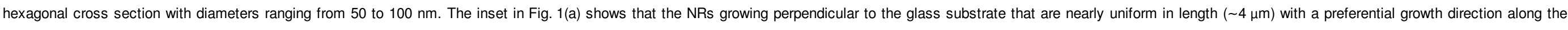

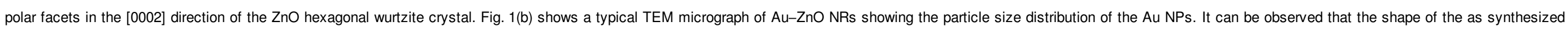
Au NPs is almost spherical showing a wide distribution of diameters ranging from 7 to 23 , which is expected since no capping agents were used during the synthesis of the Au NPs to control their sizes. 


\section{rsc_RA_c5ra16569e}

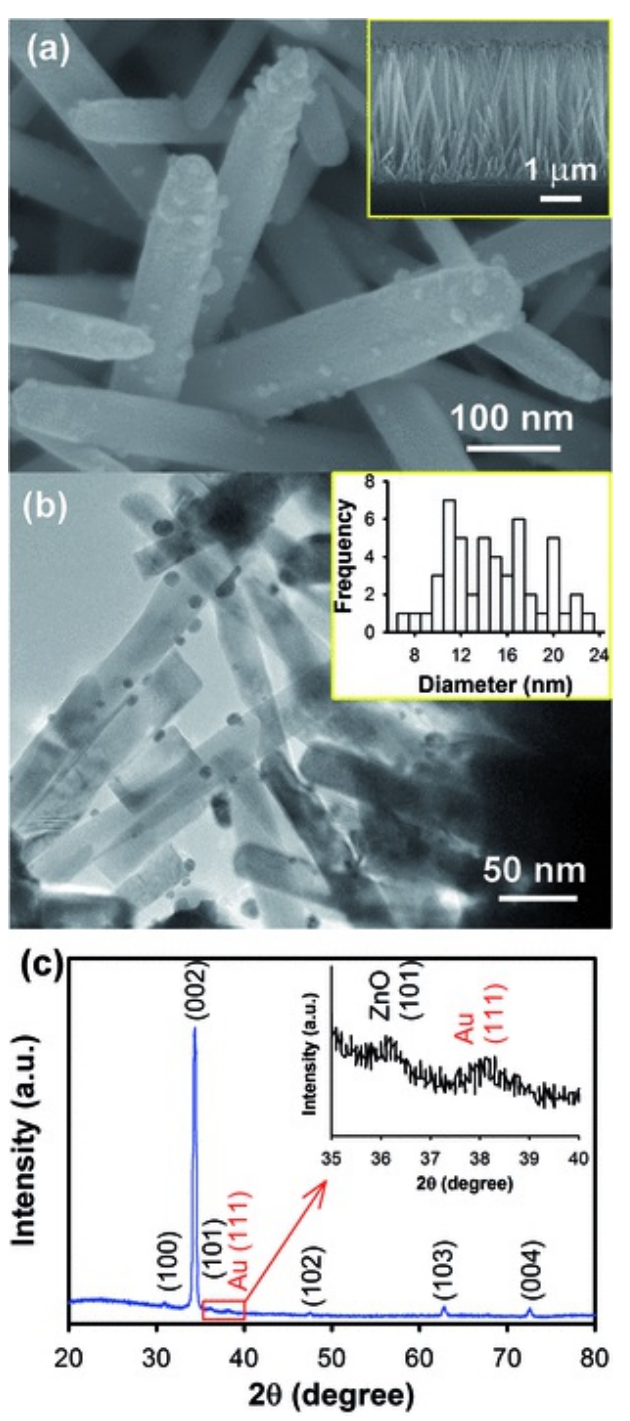

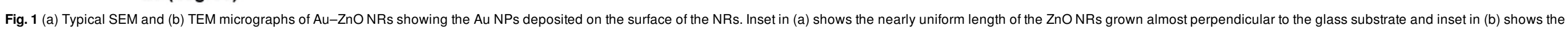

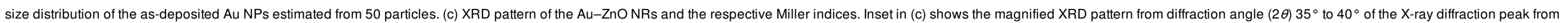
(111) crystal plane of metallic Au NPs at $2 \theta=38.2^{\circ}$. ZnO NRs were annealed at $450{ }^{\circ} \mathrm{C}$ prior to the in situ deposition of Au NPs.

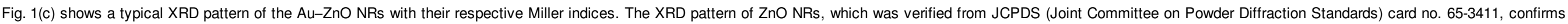

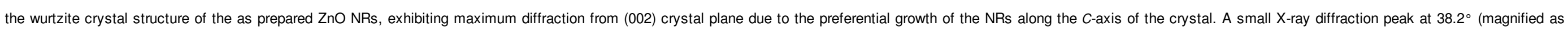
inset) corresponds to the (111) crystal plane of metallic Au (JCPDS card no. 71-4615), confirming the presence of Au NPs in the sample.

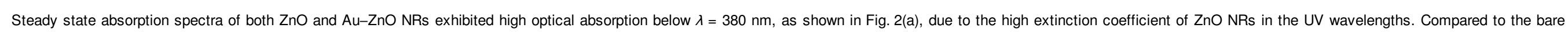

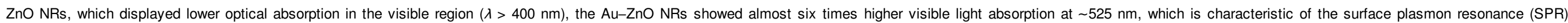

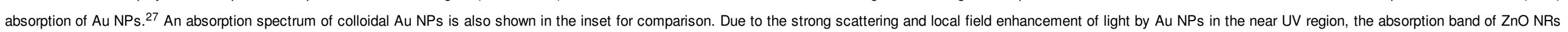




\section{rsc_RA_c5ra16569e}

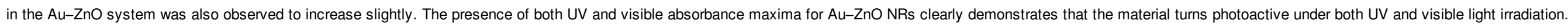
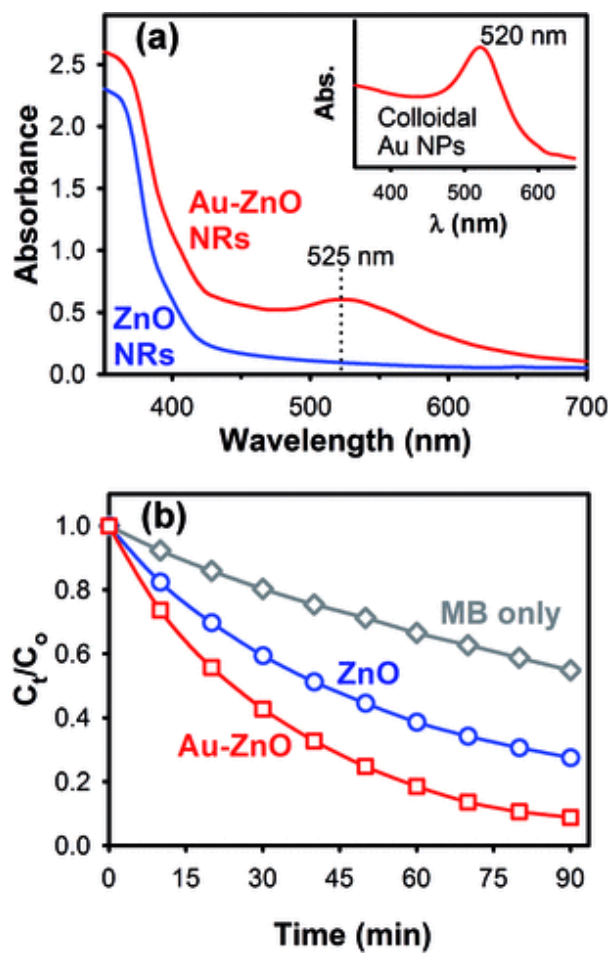

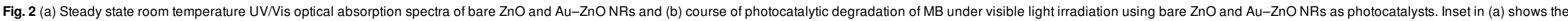
UV/Vis optical absorption spectrum of colloidal Au NPs showing the SPR peak at $520 \mathrm{~nm}$.

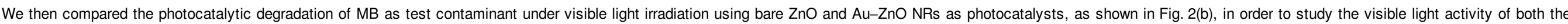

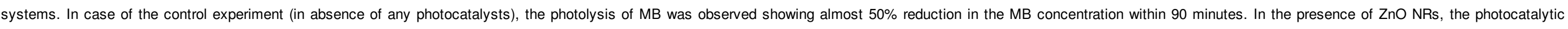

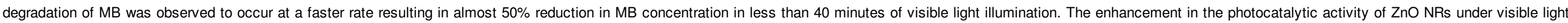

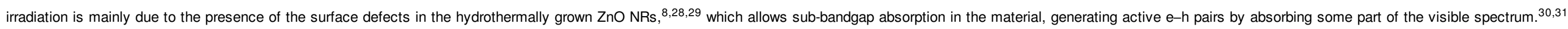

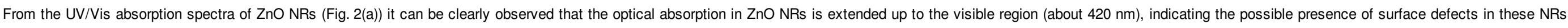
and thus making them active under visible light for photocatalytic degradation of MB. The role of surface defects is discussed in details later in this section

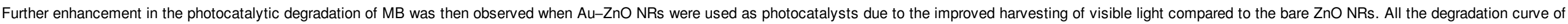

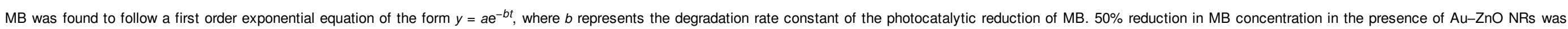

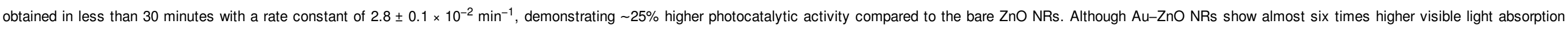

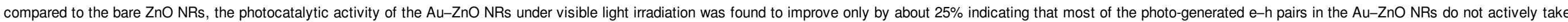

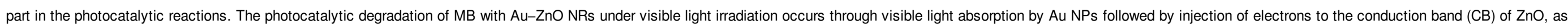

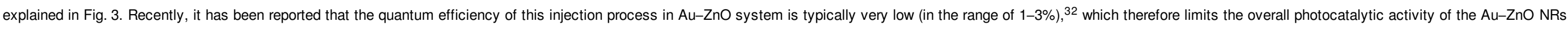
in spite of the improved visible light absorption. 


\section{rsc_RA_c5ra16569e}

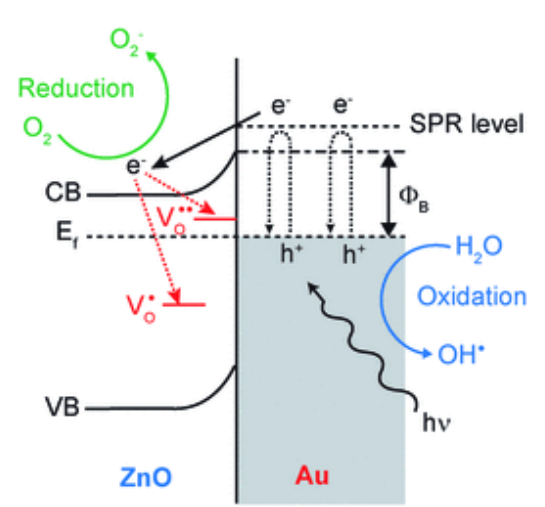

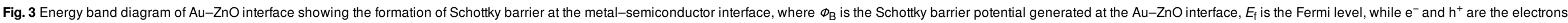

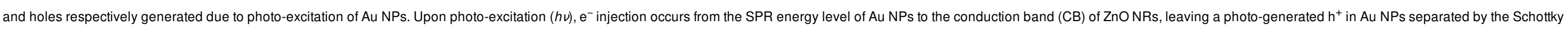
junction formed at the $\mathrm{Au}-\mathrm{ZnO}$ interface. $\mathrm{V}_{\mathrm{O}}^{\cdot}$ and $\mathrm{V}_{\mathrm{O}}^{*}$ represents oxygen vacancy defect states in ZnO NRs present mostly near the surface acting as $\mathrm{e}^{-}$trapping sites.

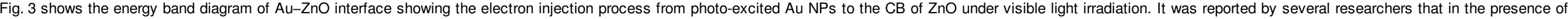

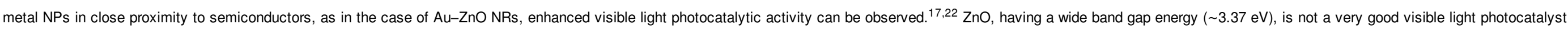

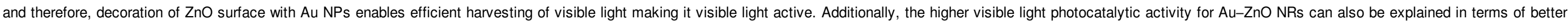

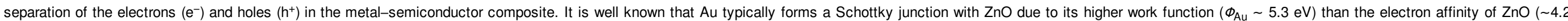

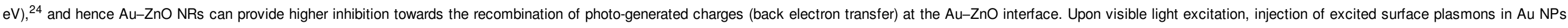

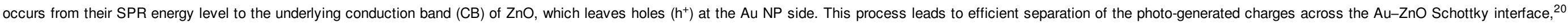
which then undergoes radical formation reactions, as shown in Fig. 3, to take part in the photocatalytic degradation of target pollutants.

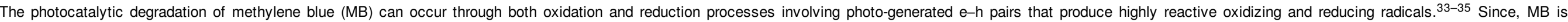

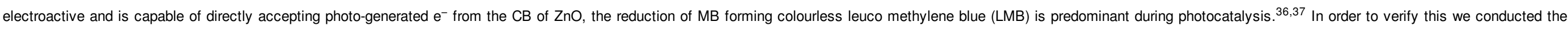

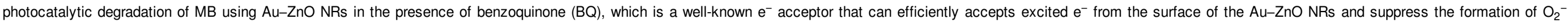

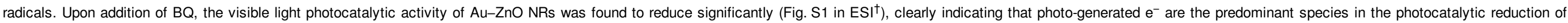

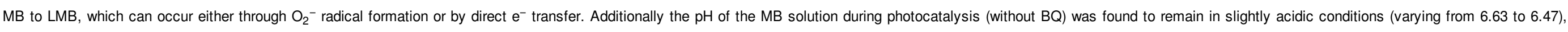
which is also not favourable for oxidation of $\mathrm{MB} .^{38}$

\section{Role of surface defects in photocatalytic activity of Au-ZnO NRs}

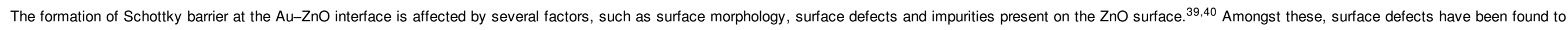

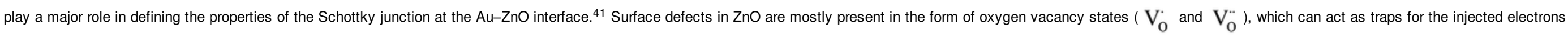

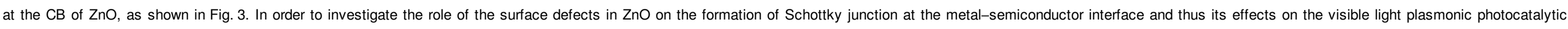

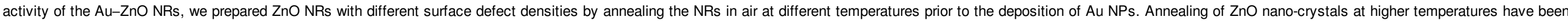
found to alter the concentrations of the defects at the crystal surface. ${ }^{42-44}$

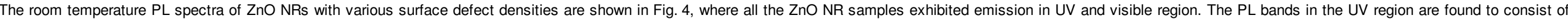

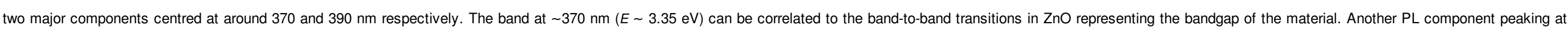

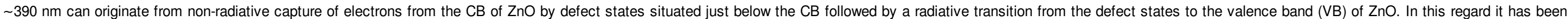




\section{rsc_RA_c5ra16569e}

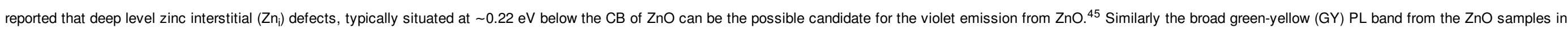

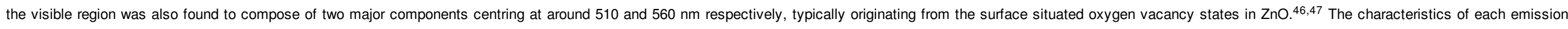

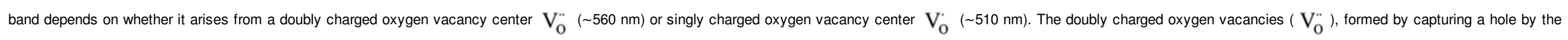

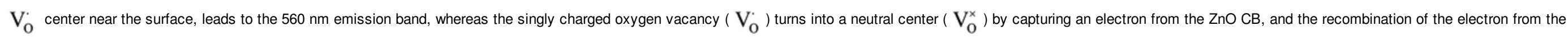
$\mathrm{V}_{\mathrm{O}}$ center to a hole at the $\mathrm{ZnO}$ VB results in the $510 \mathrm{~nm}$ emission. ${ }^{48}$

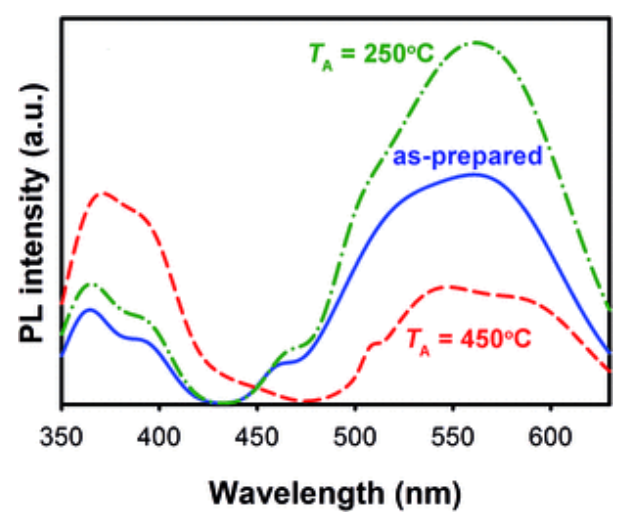

Fig. 4 Room temperature photoluminescence (PL) spectra of as-prepared and annealed $\left(250^{\circ} \mathrm{C}\right.$ and $\left.450{ }^{\circ} \mathrm{C}\right) \mathrm{ZnO} \mathrm{NRs} \mathrm{without} \mathrm{Au} \mathrm{NPs} \mathrm{obtained} \mathrm{at} \mathrm{an} \mathrm{excitation} \mathrm{wavelength} \mathrm{of} 325 \mathrm{~nm}$ ( $T_{\mathrm{A}}$ represents the annealing temperature).

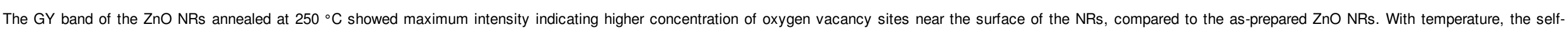

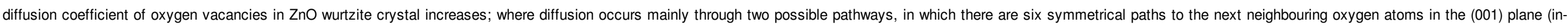

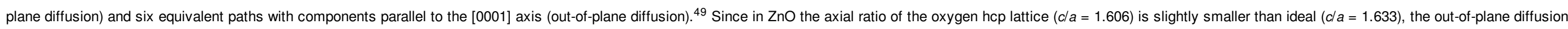

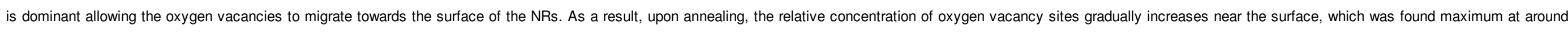

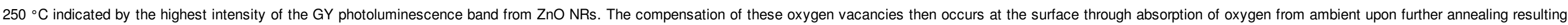

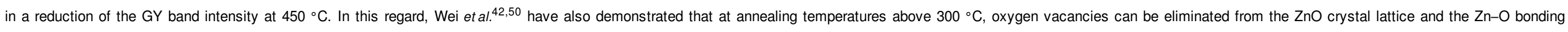
stoichiometry can be enhanced.

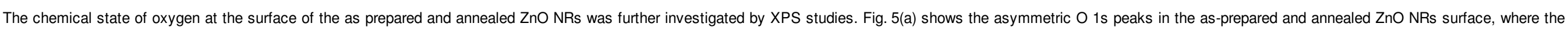

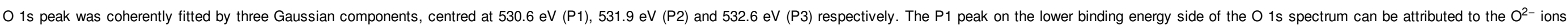

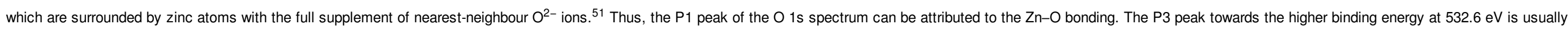

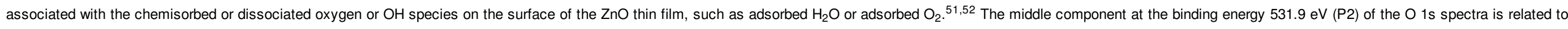

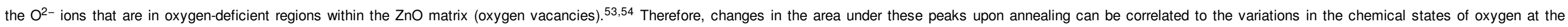
surface of the ZnO NRs. 


\section{rsc_RA_c5ra16569e}
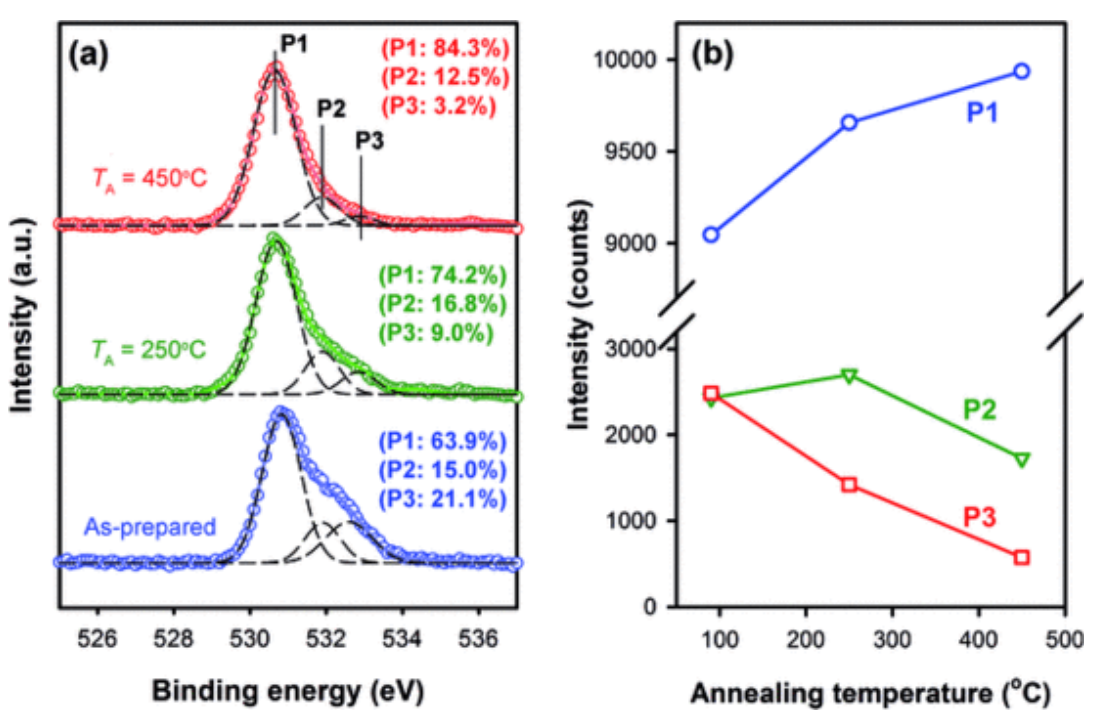

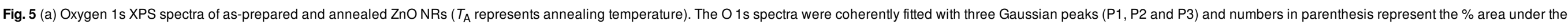
deconvoluted peaks. (b) Variations in the absolute intensities of P1, P2 and P3 as a function of the annealing temperature.

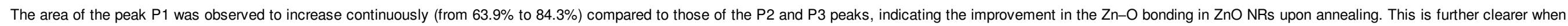

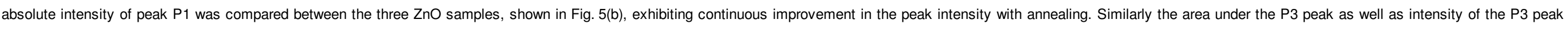

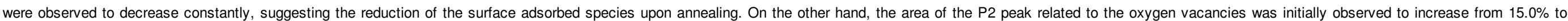

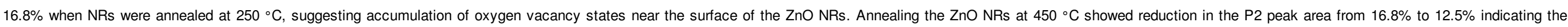

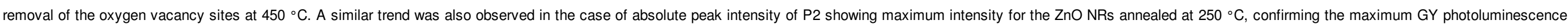
from the $250^{\circ} \mathrm{C}$ annealed $\mathrm{ZnO}$ NRs as shown in Fig. 4.

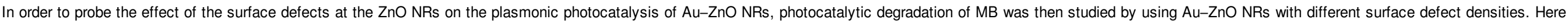

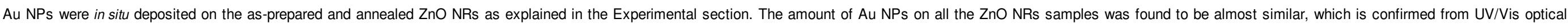

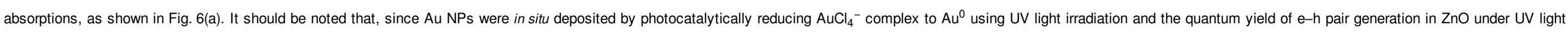

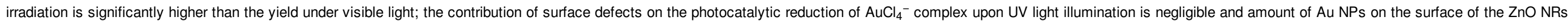
can be simply controlled by UV light irradiation time. 


\section{rsc_RA_c5ra16569e}
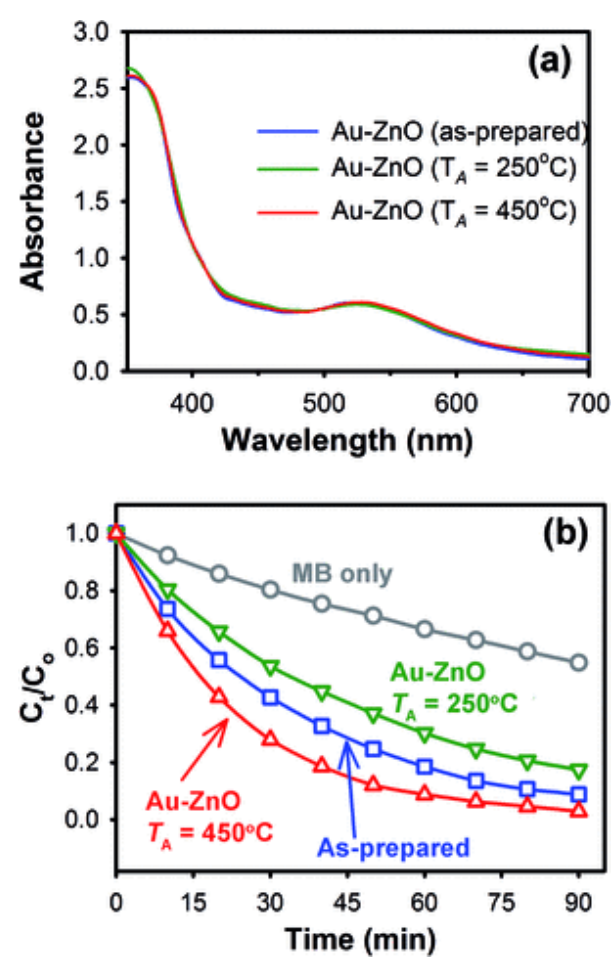

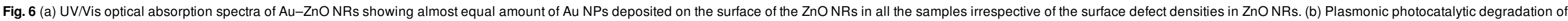
MB by the Au-ZnO NRs with different surface defect densities in the ZnO NRs.

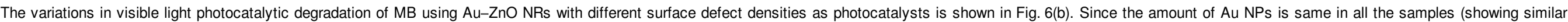

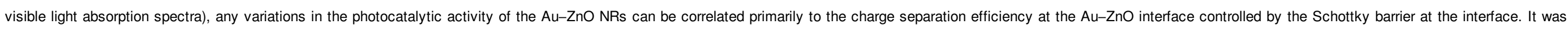

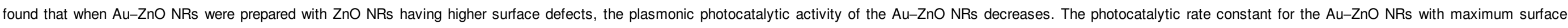

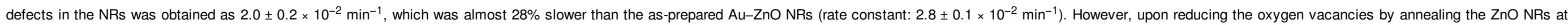

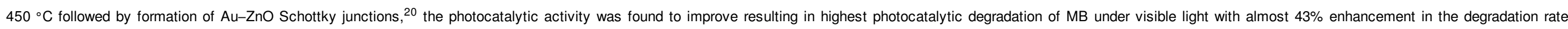

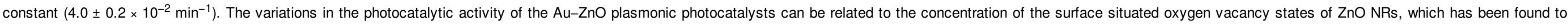
greatly influence the Schottky junction properties at the Au-ZnO NRs by acting as trap states and inducing higher band bending at the surface of the ZnO NRs.

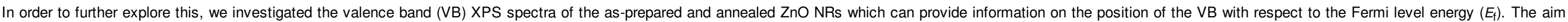

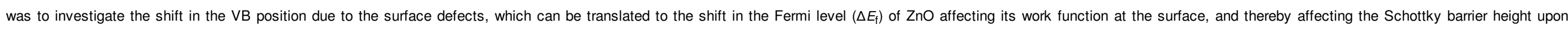

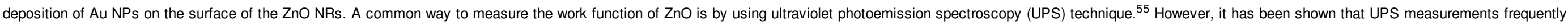

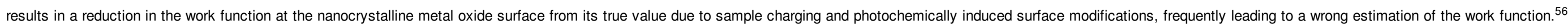

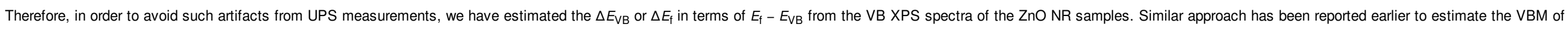
ZnO samples. ${ }^{57}$

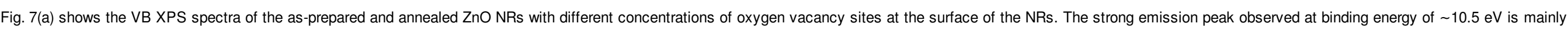

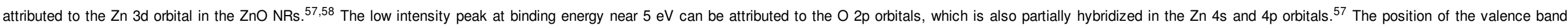

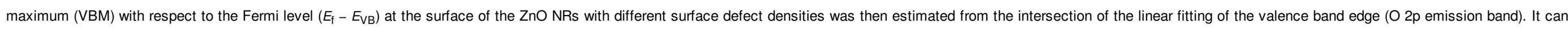




\section{rsc_RA_c5ra16569e}

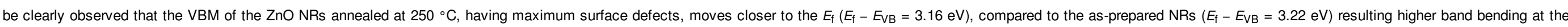

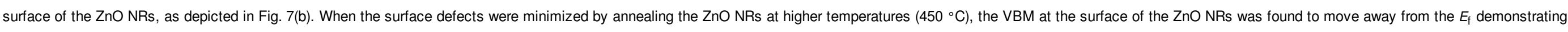

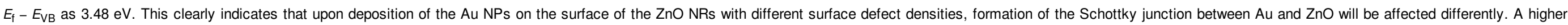

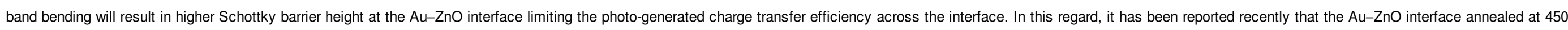
${ }^{\circ} \mathrm{C}$ possess lowest barrier height $(0.67 \mathrm{eV})$ compared to the samples annealed at $350{ }^{\circ} \mathrm{C}$ showing a barrier height of $0.72 \mathrm{eV} .{ }^{59}$

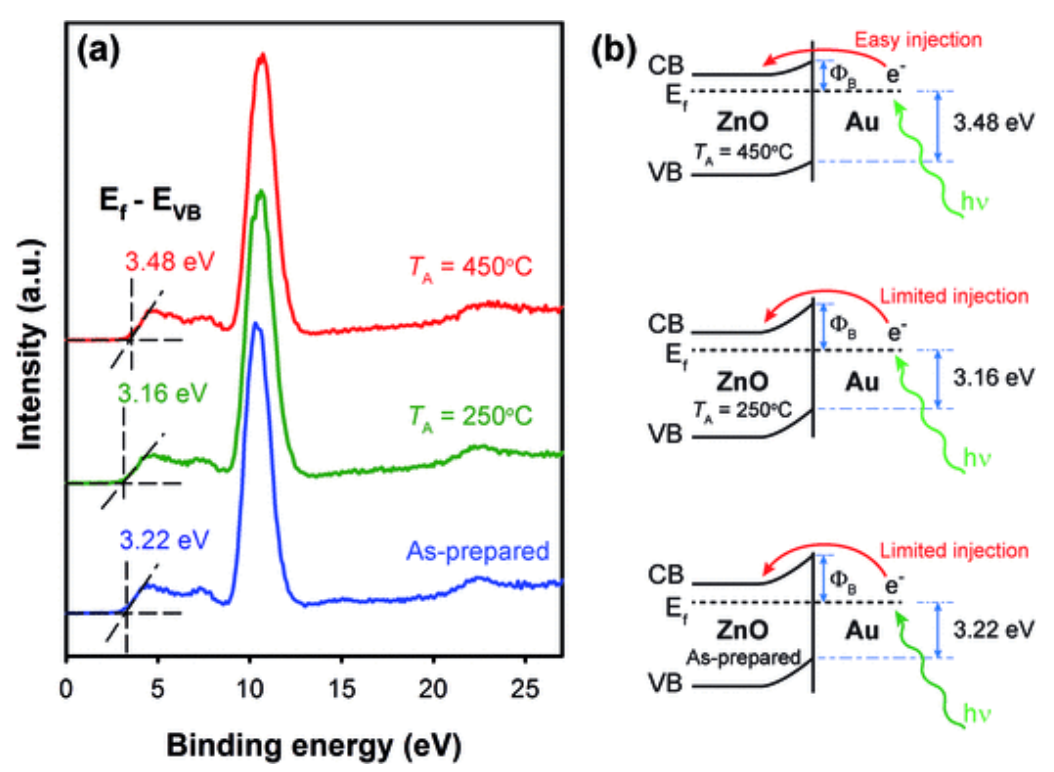

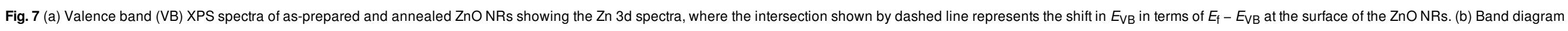
representing the formation of Schottky barrier of different height at the $\mathrm{Au}-\mathrm{ZnO}$ interface having different band bending ( $T_{\mathrm{A}}$ represents annealing temperature)

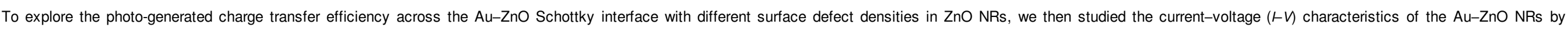

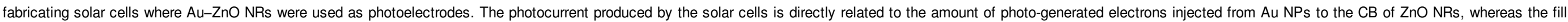

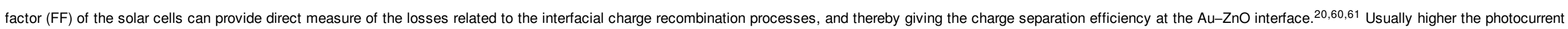
and FF, higher will be the charge transfer and charge separation efficiency at the Au-ZnO interface respectively, and hence higher will be the photocatalytic activity.

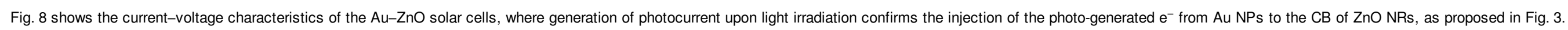

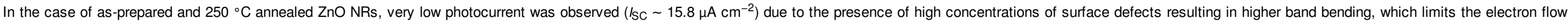

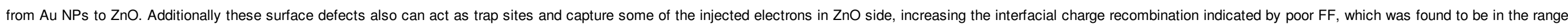

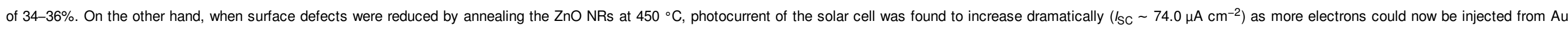

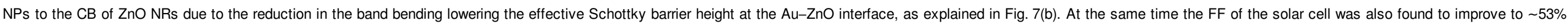

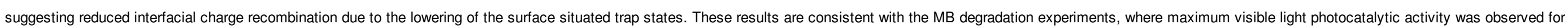
the Au-ZnO NRs having minimum surface defects due to the improved photo-generated charge transfer and charge separation efficiency across the Au-ZnO Schottky interface. 


\section{rsc_RA_c5ra16569e}

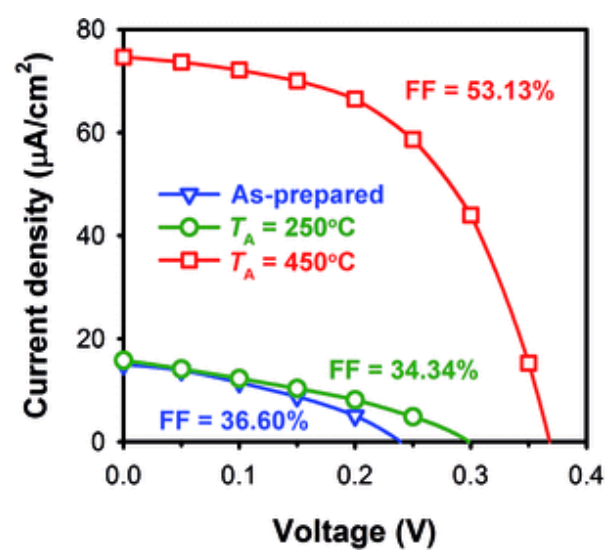

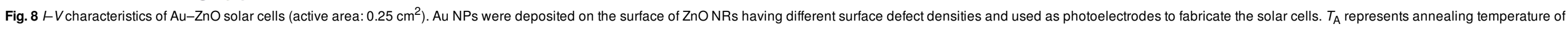
ZnO NRs prior to the deposition of Au NPs.

\section{Conclusions}

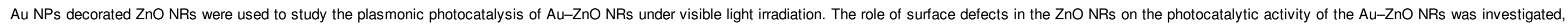

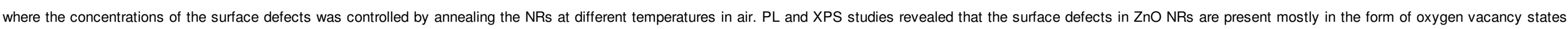

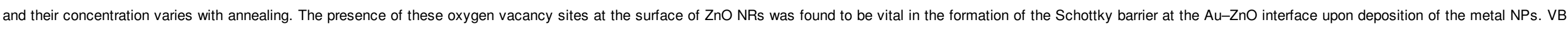

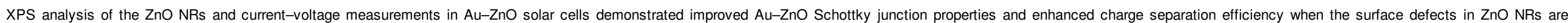

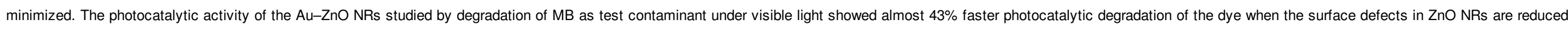

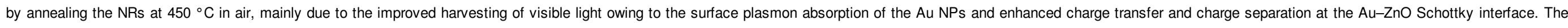
results from this study suggest that surface defects in the semiconductor play a crucial role in defining the performance of visible light driven metal-semiconductor based plasmonic photocatalysis.

\section{Acknowledgements}

The authors would like to thank the Chair in Nanotechnology, The Research Council of Oman for the financial support to carry out this research work.

\section{Notes and references}

1 M. R. Hoffmann, S. T. Martin, W. Choi and D. W. Bahnemann, Chem. Rev., 1995, 95, 69.

2 A. Mills and S. le Hunte, J. Photochem. Photobiol., A, 1997, 108, 1

3 A. Mills, R. H. Davies and D. Worsley, Chem. Soc. Rev., 1993, 22, 417.

4 R. Ullah and J. Dutta, J. Hazard. Mater., 2008, 156, 194.

5 K. G. Kanade, B. B. Kale, J. O. Baeg, S. M. Lee, C. W. Lee, S. J. Moon and H. Chang, Mater. Chem. Phys., 2007, 102, 98.

6 T. Fu, Q. Gao, F. Liu, H. Dai and X. Kou, Chin. J. Catal., 2010, 31, 797. 


\section{rsc_RA_c5ra16569e}

7 I. Nakamura, N. Negishi, S. Kutsuna, T. Ihara, S. Sugihara and K. Takeuchi, J. Mol. Catal. A: Chem., 2000, 161, 205.

8 S. Baruah, M. A. Mahmood, M. T. Z. Myint, T. Bora and J. Dutta, Beilstein J. Nanotechnol., 2010, 1, 14.

9 J. Moon, C. Y. Yun, K. W. Chung, M. S. Kang and J. Yi, Catal. Today, 2003, 87, 77.

10 M. Cheng, W. Ma, C. Chen, J. Yao and J. Zhao, Appl. Catal., B, 2006, 65, 217.

11 S. Sarkar, A. Makhal, T. Bora, K. Lakhsman, A. Singha, J. Dutta and S. K. Pal, ACS Appl. Mater. Interfaces, 2012, 4, 7027.

12 L. Wu, J. C. Yu and X. Fu, J. Mol. Catal. A: Chem., 2006, 244, 25

13 J. Liu, R. Yang and S. Li, Rare Met., 2006, 25, 636

14 J. Tian, Y. Sang, Z. Zhao, W. Zhou, D. Wang, X. Kang, H. Liu, J. Wang, S. Chen, H. Cai and H. Huang, Small, 2013, 9, 3864.

15 P. Wang, B. Huang, Y. Dai and M.-H. Whangbo, Phys. Chem. Chem. Phys., 2012, 14, 9813.

16 X. Zhang, Y. L. Chen, R.-S. Liu and D. P. Tsai, Rep. Prog. Phys., 2013, 76, 046401.

17 F. Pincella, K. Isozaki and K. Miki, Light: Sci. Appl., 2014, 3, e133.

18 F. Yan, Y. Wang, J. Zhang, Z. Lin, J. Zheng and F. Huang, ChemSusChem, 2014, 7, 101.

19 S. Sarina, E. R. Waclawik and H. Zhu, Green Chem., 2013,15, 1814.

20 T. Bora, H. H. Kyaw, S. Sarkar, S. K. Pal and J. Dutta, Beilstein J. Nanotechnol., 2011, 2, 681.

21 W. He, H.-K. Kim, W. G. Wamer, D. Melka, J. H. Callahan and J.-J. Yin, J. Am. Chem. Soc., 2013, 136, 750.

22 P. Li, Z. Wei, T. Wu, Q. Peng and Y. Li, J. Am. Chem. Soc., 2011, 133, 5660.

23 L. J. Brillson, H. L. Mosbacker, M. J. Hetzer, Y. Strzhemechny, D. C. Look, G. Cantwell, J. Zhang and J. J. Song, Appl. Surf. Sci., 2008, 254, 8000.

24 L. J. Brillson and L. Yicheng, J. Appl. Phys., 2011, 109, 121301.

25 A. Sugunan, H. C. Warad, M. Boman and J. Dutta, J. Sol-Gel Sci. Technol., 2006, 39, 49.

26 D. Li, J. T. McCann, M. Gratt and Y. Xia, Chem. Phys. Lett., 2004, 394, 387.

27 Y. K. Mishra, S. Mohapatra, R. Singhal, D. K. Avasthi, D. C. Agarwal and S. B. Ogale, Appl. Phys. Lett., 2008, 92, 043107.

28 X. Zhang, J. Qin, Y. Xue, P. Yu, B. Zhang, L. Wang and R. Liu, Sci. Rep., 2014, 4, 1.

29 Y. Peng, Y. Wang, Q.-G. Chen, Q. Zhu and A. W. Xu, CrystEngComm, 2014, 16, 7906.

30 S. R. A. Raza, Y. T. Lee, Y.-G. Chang, P. J. Jeon, J. H. Kim, R. Ha, H.-J. Choi and S. Im, Phys. Chem. Chem. Phys., 2013, 15, 2660.

31 R. M. Sheetz, I. Ponomareva, E. Richter, A. N. Andriotis and M. Menon, Phys. Rev. B: Condens. Matter Mater. Phys., 2009, 80, 195314. 


\section{rsc_RA_c5ra16569e}

32 A. Pescaglini, A. Martín, D. Cammi, G. Juska, C. Ronning, E. Pelucchi and D. lacopino, Nano Lett., 2014, 14, 6202.

33 A. Mills and J. Wang, J. Photochem. Photobiol., A, 1999, 127, 123.

34 Q. Xiang, J. Yu and P. K. Wong, J. Colloid Interface Sci., 2011, 357, 163.

35 M. Misra, R. K. Gupta, A. K. Paul and M. Singla, J. Power Sources, 2015, 294, 580.

36 L. I. Grossweiner, Radiat. Res. Rev., 1970, 2, 345.

37 S. Baruah, S. S. Sinha, B. Ghosh, S. K. Pal, A. K. Raychaudhuri and J. Dutta, J. Appl. Phys., 2009, 105, 0743081.

38 J. M. Bauldreay and M. D. Archer, Electrochim. Acta, 1983, 28, 1515.

39 B. J. Coppa, C. C. Fulton, S. M. Kiesel, R. F. Davis, C. Pandarinath, J. E. Burnette, R. J. Nemanich and D. J. Smith, J. Appl. Phys., 2005, $97,103517$.

40 H. L. Mosbacker, Y. M. Strzhemechny, B. D. White, P. E. Smith, D. C. Look, D. C. Reynolds, C. W. Litton and L. J. Brillson, Appl. Phys. Lett., 2005, 87, 012102.

41 L. J. Brillson, H. L. Mosbacker, M. J. Hetzer, Y. Strzhemechny, G. H. Jessen, D. C. Look, G. Cantwell, J. Zhang and J. J. Song, Appl. Phys. Lett., $2007,90,102116$.

42 S. Wei, J. Lian and H. Wu, Mater. Charact., 2010, 61, 1239.

43 Y. Zhang, W. Fa, F. Yang, Z. Zheng and P. Zhang, lonics, 2010, 16, 815.

44 G. P. Daniel, V. B. Justinvictor, P. B. Nair, K. Joy, P. Koshy and P. V. Thomas, Phys. B Condens. Matter, 2010, 405, 1782.

45 C. H. Ahn, Y. Y. Kim, D. C. Kim, S. K. Mohanta and H. K. Cho, J. Appl. Phys., 2009, 105, 013502.

46 A. van Dijken, E. A. Meulenkamp, D. Vanmaekelbergh and A. Meijerink, J. Lumin., 2000, 90, 123.

47 K. Vanheusden, W. L. Warren, C. H. Seager, D. R. Tallant, J. A. Voigt and B. E. Gnade, J. Appl. Phys., 1996, 79, 7983.

48 J. D. Ye, S. L. Gu, F. Qin, S. M. Zhu, S. M. Liu, X. Zhou, W. Liu, L. Q. Hu, R. Zhang, Y. Shi and Y. D. Zheng, Appl. Phys. A, 2005, 81, 759.

49 P. Erhart and K. Albe, Phys. Rev. B: Condens. Matter Mater. Phys., 2006, 73, 115207.

50 X. Q. Wei, Z. G. Zhang, M. Liu, C. S. Chen, G. Sun, C. S. Xue, H. Z. Zhuang and B. Y. Man, Mater. Chem. Phys., 2007, 101, 285.

51 M. Chen, X. Wang, Y. H. Yu, Z. L. Pei, X. D. Bai, C. Sun, R. F. Huang and L. S. Wen, Appl. Surf. Sci., 2000, $158,134$.

52 S. Major, S. Kumar, M. Bhatnagar and K. L. Chopra, Appl. Phys. Lett., 1986, 49, 394.

53 P. T. Hsieh, Y. C. Chen, K. S. Kao and C. M. Wang, Appl. Phys. A, 2008, 90, 317.

54 T. Szörényi, L. D. Laude, I. Bertóti, Z. Kántor and Z. Geretovszky, J. Appl. Phys., 1995, 78, 6211.

55 K. Jacobi, G. Zwicker and A. Gutmann, Surf. Sci., 1984, 141, 109.

56 S. Gutmann, M. Conrad, M. A. Wolak, M. M. Beerbom and R. Schlaf, J. Appl. Phys., 2012, 111, 123710. 


\section{rsc_RA_c5ra16569e}

57 A. G. Joshi, S. Sahai, N. Gandhi, Y. G. R. Krishna and D. Haranath, Appl. Phys. Lett., 2010, 96, 123102.

58 M. Gabás, S. Gota, J. R. Ramos-Barrado, M. Sánchez, N. T. Barrett, J. Avila and M. Sacchi, Appl. Phys. Lett., 2005, 86, 042104.

59 J. D. Hwang, F. H. Wang, C. Y. Kung, M. J. Lai and M. C. Chan, J. Appl. Phys., 2014, 115, 173110.

60 I. Mora-Seró, S. Giménez, F. Fabregat-Santiago, R. Gómez, Q. Shen, T. Toyoda and J. Bisquert, Acc. Chem. Res., 2009, 42, 1848.

61 A. Alkaya, R. Kaplan, H. Canbolat and S. S. Hegedus, Renewable Energy, 2009, 34, 1595

\section{Queries and Answers}

Query: For your information: You can cite this article before you receive notification of the page numbers by using the following format: (authors), RSC Adv., (year), DOI: 10.1039/c5ra16569e. Answer: T. Bora, M. T. Z. Myint, S. H. Al-Harthi and J. Dutta, RSC Adv., 2015, DOI: 10.1039/c5ra16569e.

Query: Please carefully check the spelling of all author names. This is important for the correct indexing and future citation of your article. No late corrections can be made. Answer: Correct

Query: Please check that the inserted Graphical Abstract text is suitable. Please ensure that the text is no longer than 250 characters (including spaces).

Answer: Correct 